\title{
The Feasibility and Effectiveness of Interactive Multimedia using Gerlach and Ely Model in Learning Planning Courses
}

\author{
Erma Yulia \\ \{e-mail: ermayulia@unimed.ac.id\} \\ Universitas Negeri Medan, Medan Indonesia
}

\begin{abstract}
This study discusses about utilization of information technology and communication's equipment as learning activity and teaching effectively. The objective of this research is to get interactive multimedia on learning planning courses such as, textbook of learning planning and e-learning. The method used is research method and development from Borg and Gall. The steps of development of learning material oriented on Gerlach and Ely method which consist of determining material, goal, appraising entry behavior, determining strategy, making group, allocating time and place, choosing study source, evaluation, and feed back. The data aggregation techniques do by observation and questioner. Expedience of learning media obtained by doing expert validation, one to one evaluation, small group evaluation and field trial. The conclusion of this research resulting interactive multimedia courses material which give understanding about corrupting and non-corrupting experiment, and increasing the output of student value from pre-test and post-test.
\end{abstract}

Keywords: interactive multimedia, Borg and Gall, Gerlach and Ely

\section{Introduction}

Facing the era of globalization, various challenges related to future demands that arouse public awareness of the role of Higher Education (PT), especially in improving the function of higher education relevant to community development. Conny stated that the development of human capacity or Human Capacity Development (HCD) is the result of interaction between individuals and communities who have chance to participate. HCD refers to the constellation of skills, attitudes and behaviors in carrying out life towards independence, while at the same time having high competitiveness and resilience to the turmoil of the world economy [1].

The efforts to improve student achievement are constantly being carried out by higher education institutions including Medan State University. The learning process is identical to the process of delivering information or the communication process. In connection with that, the learning activities needed a media that functioning as the learning aid for the process of delivering learning material. One important thing that needs attention is that students should not be alienated from learning media, especially computer-based media. 
Multimedia or computer based learning has five advantages, namely: (1) effective in improving student mastery in all levels of education; (2) it is very effective in improving student mastery at the elementary school level, which continues at the secondary level through to college; (3) has a positive effect on student attitudes toward subject matter, learning and on computer technology; (4) can save time for learning; (5) Research findings from various studies and with different methods and different student settings have conclusive consistency [2].

To develop multimedia-based learning must use a development model. The development model in this study uses the Gerlach and Ely model as shown in figure 1, which is a systematic way of identifying, developing, and evaluating a set of materials and strategies aimed at achieving certain learning goals.

Based on the advantages possessed by learning by using multimedia, learning needs to be developed by combining some of the latest computer applications that so far have not been available in the Material Testing course. With this multimedia learning, the expected outcome is high technology and is the result of creativity in educational innovation. Especially in providing learning media that can improve student competencies.

The development of multimedia-based learning media must be carried out gradually and thoroughly based on one model. In this study the development of instructional media refers to the Gerlach and Ely models. The advantage of the Gerlach \& Ely model lies in the initial ability tests before learning activities. Besides that this model is very thorough in planning and implementing learning. This can be seen from the planning of grouping learning, the division of time for each activity, and the arrangement of the learning space. In accordance with its class-oriented characteristics, this development model is suitable for small-scale learning.

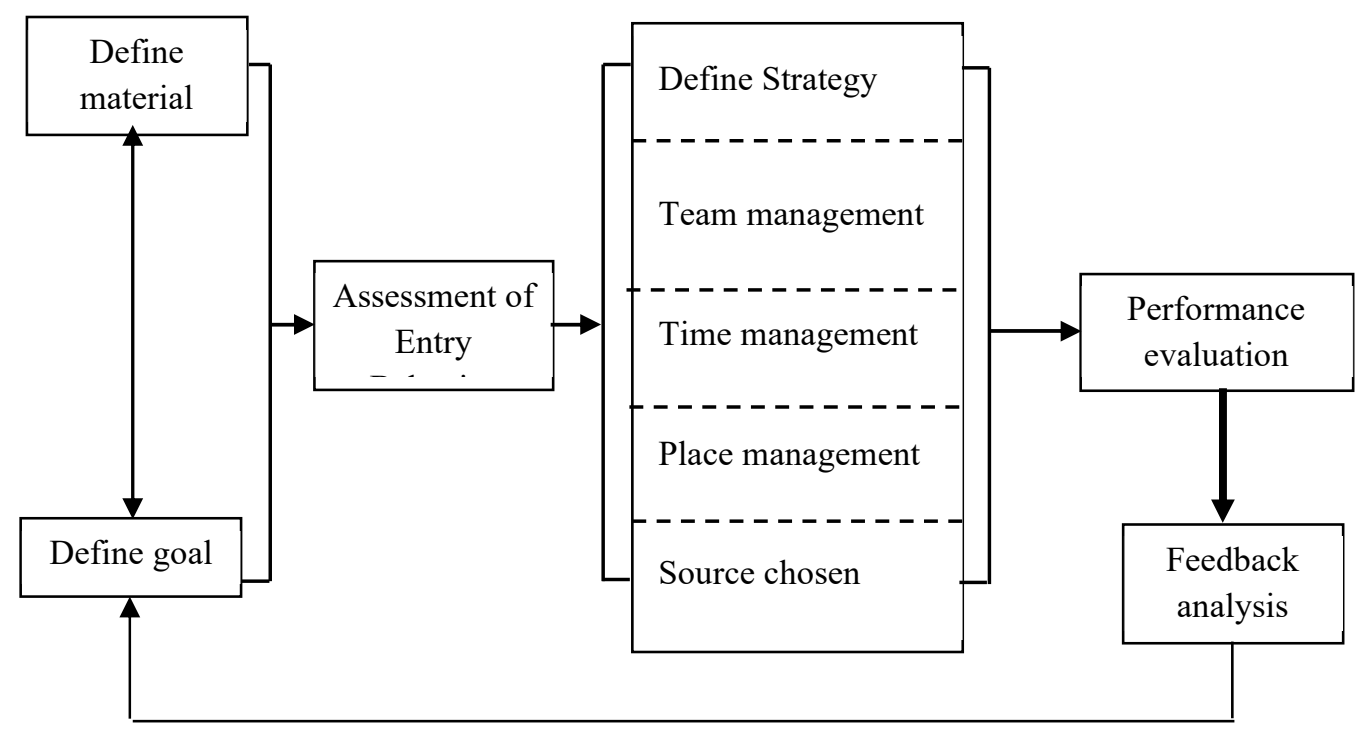

Fig 1. Steps of Gerlach \& Ely Development Model 
The understanding of the model in this study refers to the definition expressed by Miarso [3] that the model is a representation of a process in free and / or narrative form, by showing the main elements and their structure. In this case it is possible to interpret narrative models in graphic form, or vice versa. Robins define that "model is an abstraction of reality; a simplified representation of some real world phenomenon". That is, the model is a representation of several phenomena that exist in the real world [4].

According to Miarso there are various kinds of models, three of which are (1) conceptual models, which are in essence an embodiment of a theory in other words a conceptualization of theories; (2) procedural model, which is prescriptive in nature means giving a prescription about how something is. In essence is an embodiment of the stages of the process of forming a model; and (3) physical model, is a model in physical form [5].

Gustafson and Branch said that 'the development of instructional media' consisted of at least five main activities, namely: (1) analyzing the conditions of learning and the needs of learners; (2) designing a series of specifications that are effective, efficient, and relevant to the learning environment; (3) developing all materials for all learners and material management; (4) implementation of the learning design results; and (5) formative and summative evaluation of the results of development [6]. Byrnes said that the constructivist view is not new, but is an amalgamation of various approaches.

Seels dan Richey defines multimedia is a collection of material in a variety of different media (text, graphics, audio, visual, etc.) that is designed to be presented in an integrated manner through the use of a medium (ie computer) [7]. While Schwier and Misanchuk define that Multimedia: An instructional program which includes a variety of integrated sources in the instruction. The program is intentionally designed in segments, and viewer responses to structured opportunities (e.g., menus, problems, simulated crises, questions, virtual environments) influence the sequence, size, content, and shape of the program [8].

This research aims to develop learning media for testing multimedia based on interactive multimedia using Gerlach and Ely models. The feasibility of learning media for interactive multimedia-based material testing using Gerlach and Ely models, and knowing the effectiveness of interactive multimedia-based learning media testing materials using Gerlach and Ely models. 


\section{Research Methods}

\subsection{Steps of research assessment}

The development of learning media which is used as the basis for this research and development is the Gerlach \& Ely development model as shown in Figure 2.

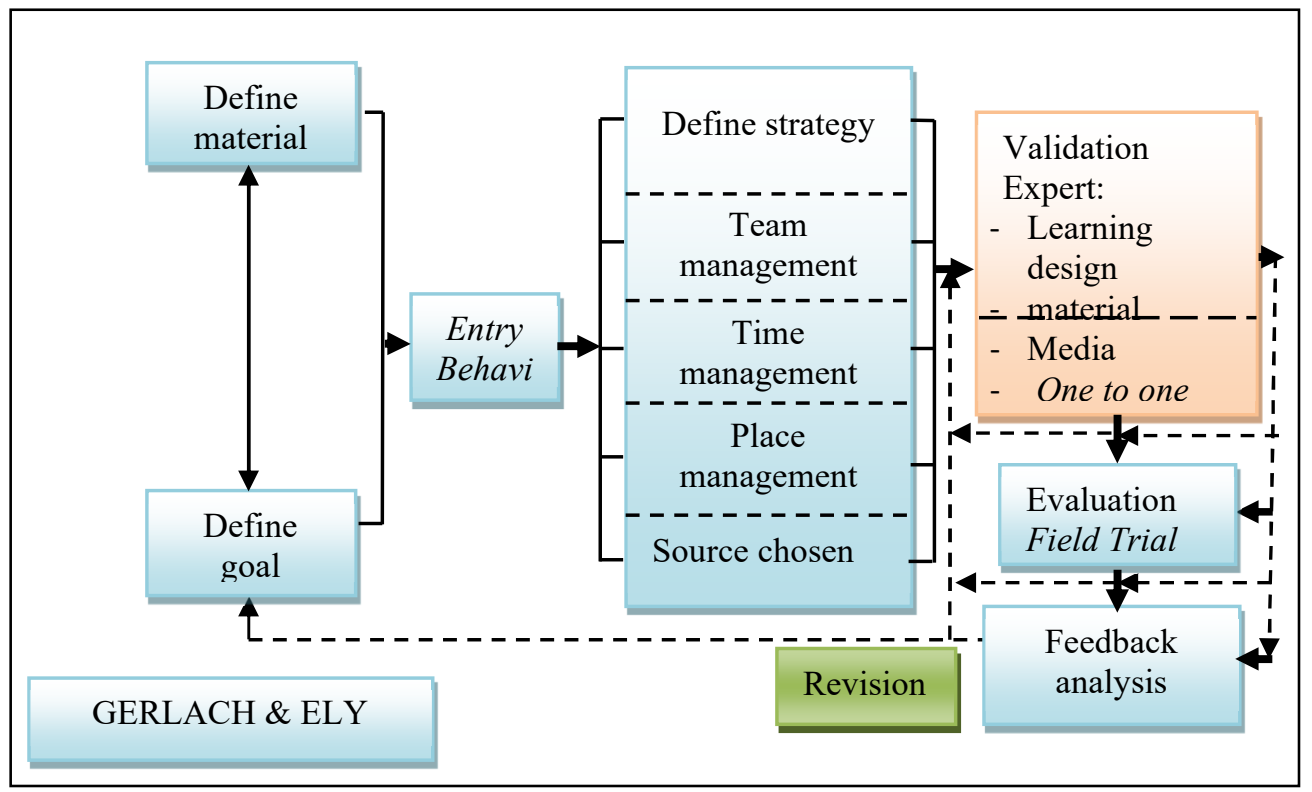

Fig 2. steps of research

\subsection{Data Collection and Analysis Techniques}

The data in this study were analyzed qualitatively, and the data collection instruments developed in this study were related to the data collection techniques carried out at each stage of the study, namely: a list of questions in the form of a questionnaire, used to ask questions and observations in the development and validation stages experts, as well as learning outcomes tests in the form of objective tests and action tests used to measure student competency improvement.

\section{Result}

\subsection{Result of the development}

The results of the development of interactive multimedia material testing courses, include three forms, namely 1) conceptual development; 2) procedural development; and 3) physical development as shown in figure 3 . 


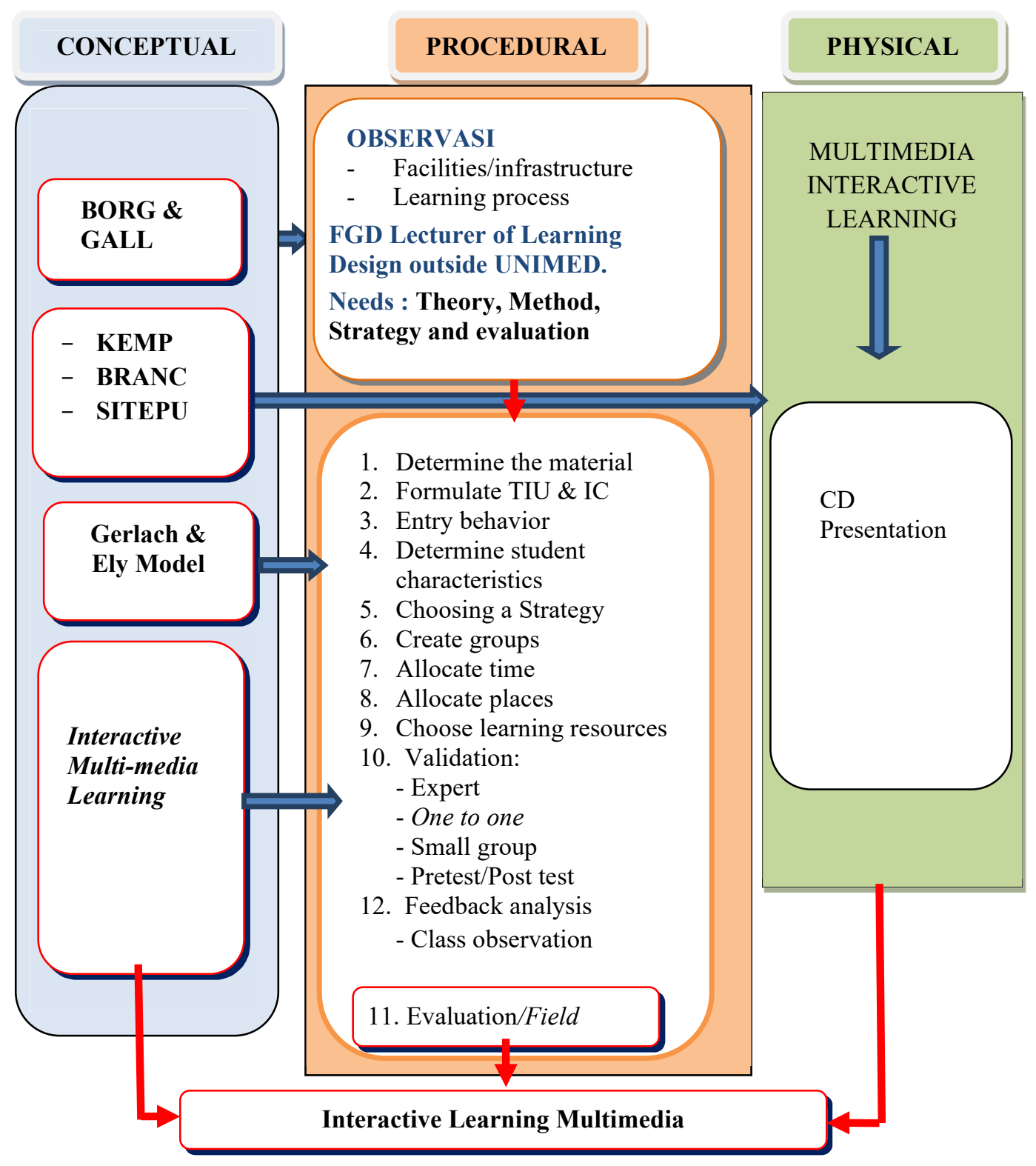

Fig 3. Result of development 


\subsubsection{Result of conceptual development}

Conceptual development is an embodiment of the conceptualization of the theories and principles underlying the formation of interactive multimedia-based learning in this material testing course. The results of conceptual development can be seen in Figure 4.

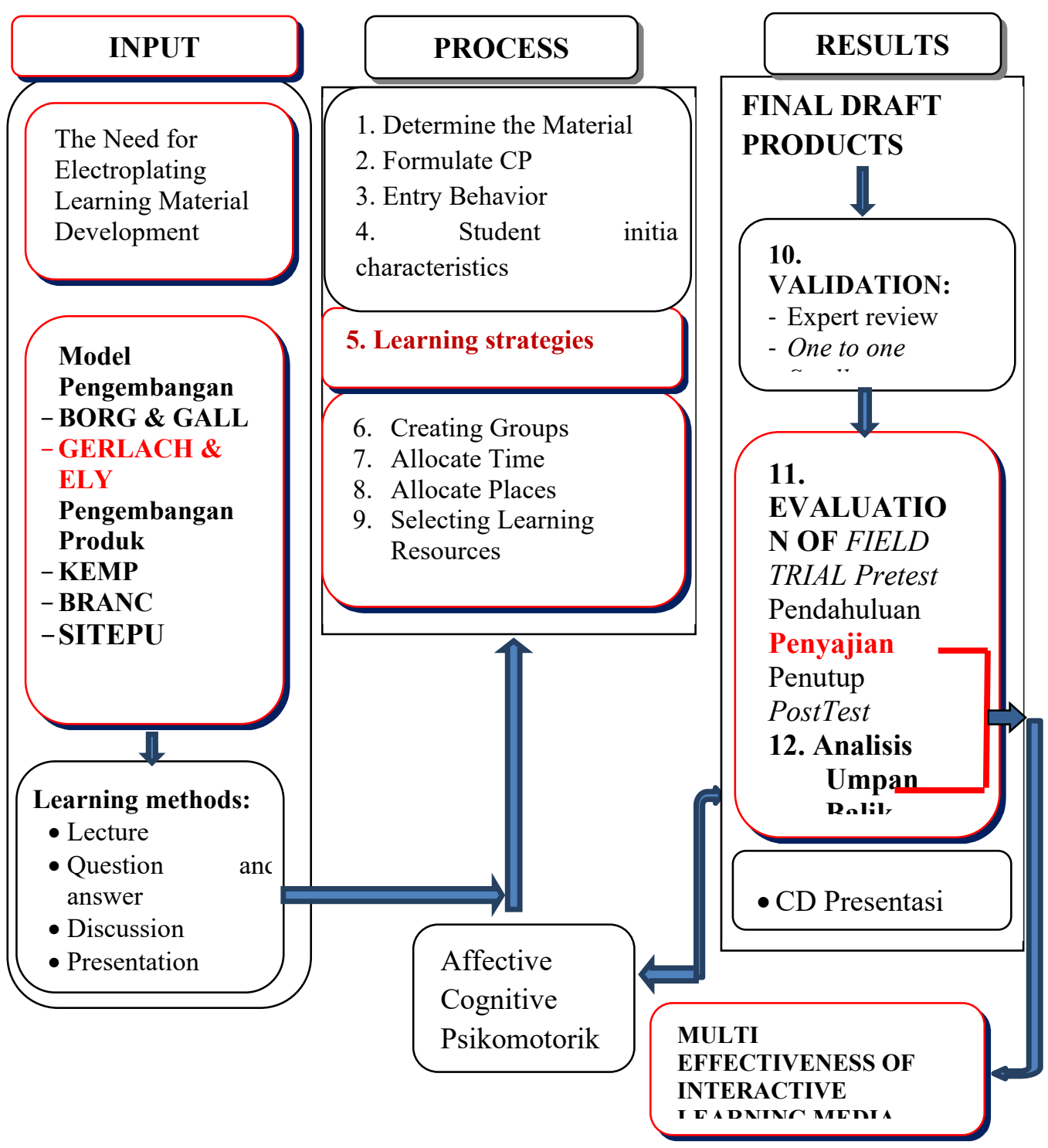

Fig 4. Conceptual Development Scheme 


\subsubsection{Results of Procedural Development}

The result of procedural development is the realization of the stages in the formation of interactive multimedia-based learning media. This procedural development is a combination of the Gerlach and Ely development model with the Dick and Carey development model, which consists of 10 steps namely: (1) determining the material; (2) formulating learning objectives; (3) Entry Behavior; (4) choosing a learning strategy; (5) creating groups; (6) allocating time; (7) allocating space; (8) choosing learning resources; (9) evaluation; (10) feedback analysis, developed and modified to 12. The complete procedural development scheme can be seen in Figure 5.

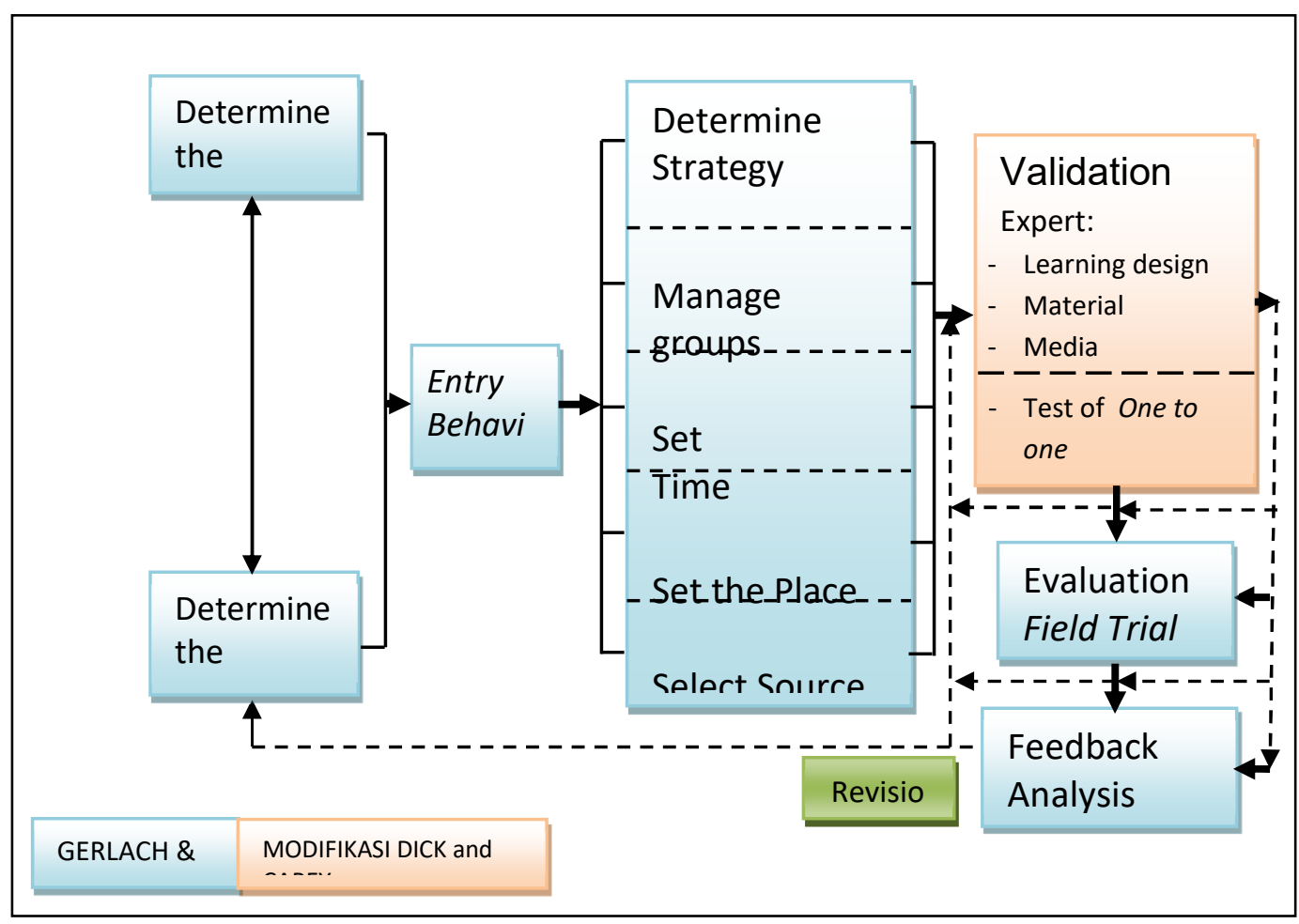

Fig 5. Procedural Development Scheme

\subsubsection{Results of Physical Development}

Physical development in the form of physical form of Learning Design product courses, in the form of printed textbooks and interactive multimedia in Compact Discs (CD). The appearance of the front and back cover of the printed textbook is shown in Figure 6, 7, 8, 9, 10. 


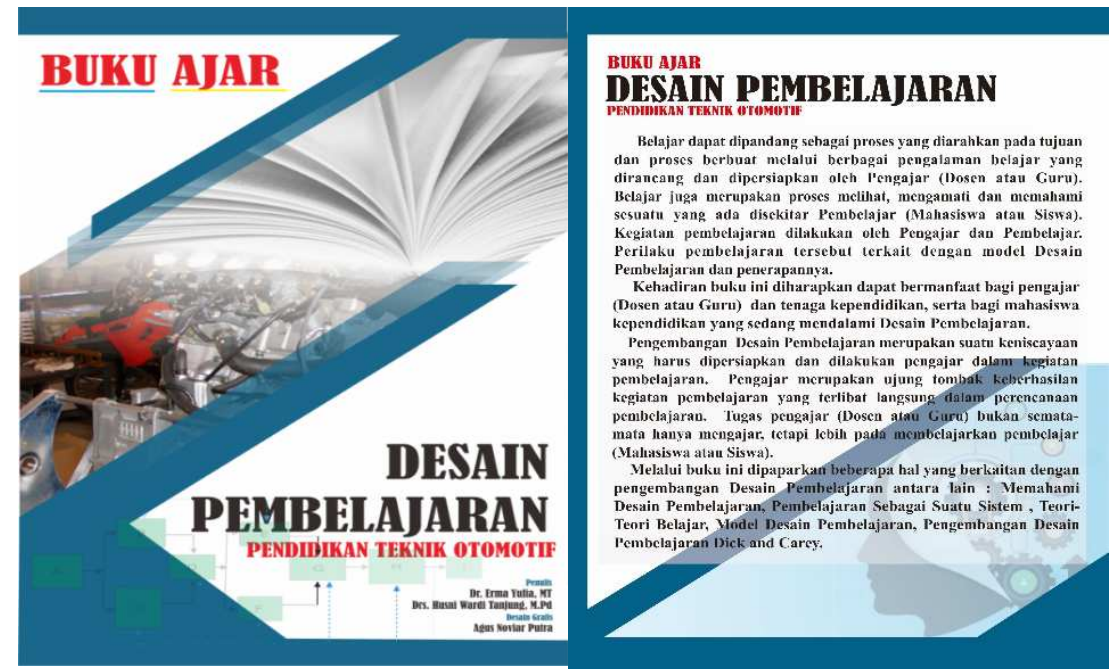

Fig 6. Learning Textbook Design Learning

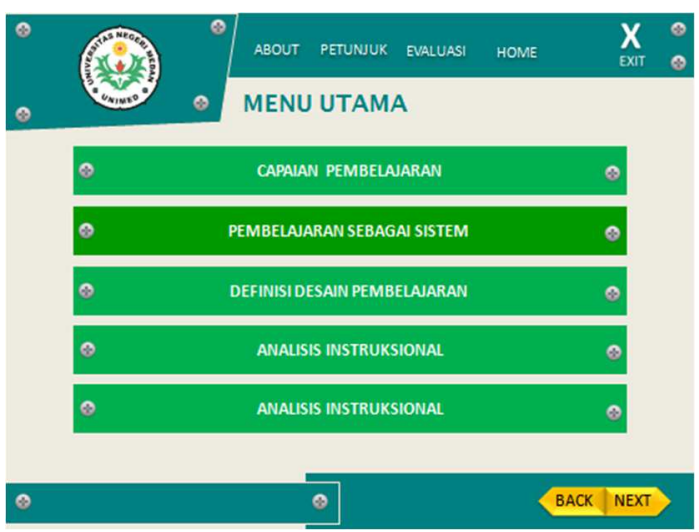

Fig 7. The main menu Interactive Multimedia Learning

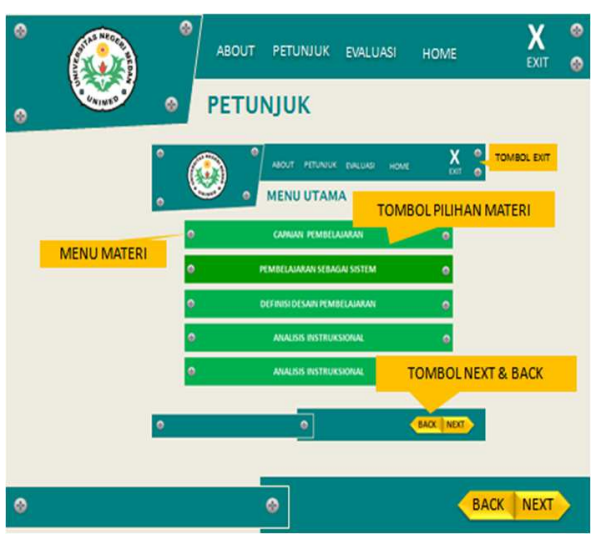

Fig 8. Display of Interactive Multimedia Operating Instructions 


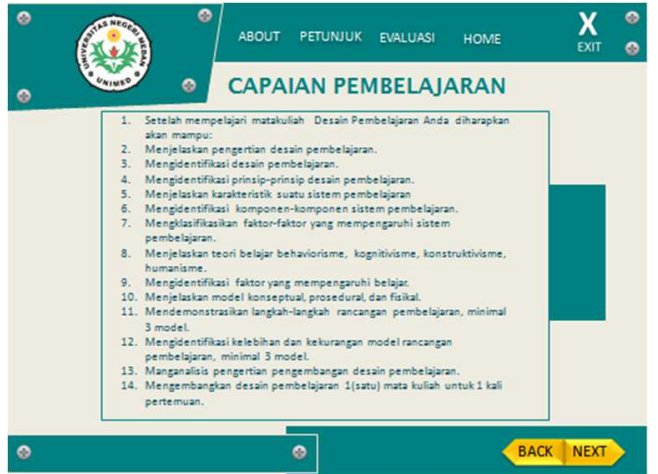

Fig 9. Display of Learning Achievement in Learning Design Subjects

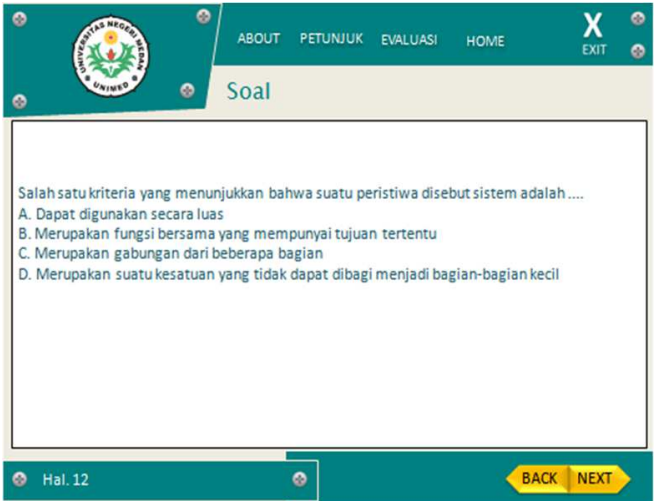

Fig 10. Display of Interactive Multimedia Evaluation Questions

\subsection{Feasibility of Interactive Multimedia}

Furthermore, for the perfection of products resulting from the development of interactive multimedia, a feasibility test is carried out by experts, instructional design experts, material experts and instructional media experts.

\subsubsection{Feasibility Learning Expert Design}

Inputs and suggestions from learning design experts are divided into 4 (four) aspects namely learning objectives, learning strategies, material preparation and evaluation tools. Comments / inputs for improvement / revision of the question items are given in the Likert scaling score 1 to 5 . The assessment of the learning design expert is shown in the diagram in Figure 11.

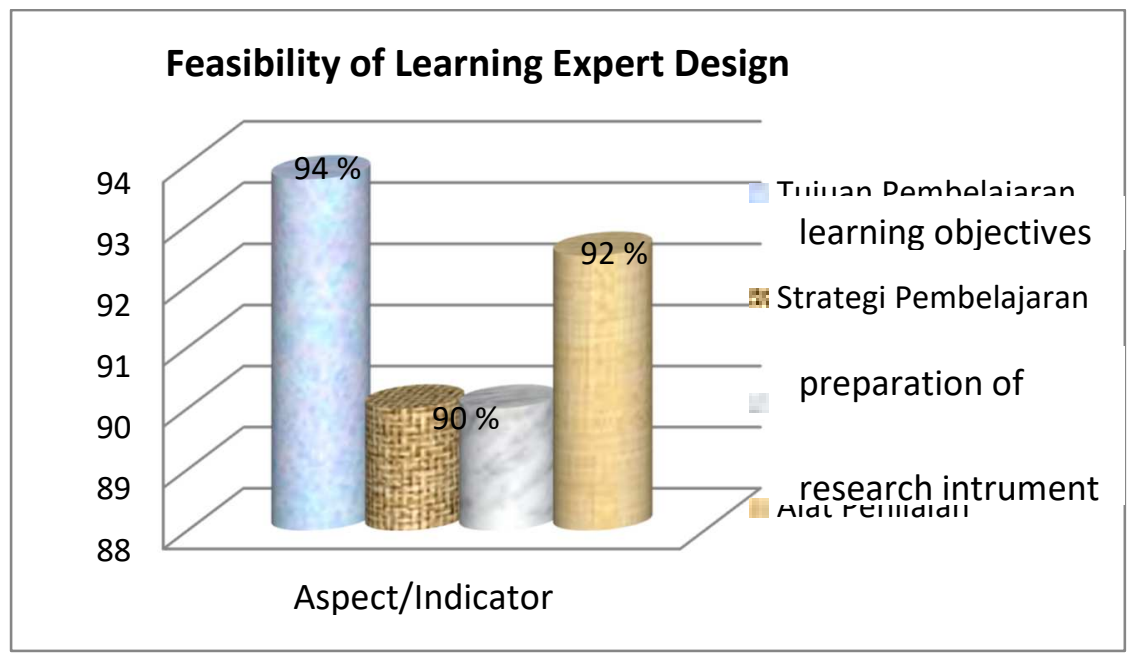

Fig 11. Average Learning Design Expertise Feasibility Score 
The mean score given by the learning design expert for 4 (four) aspects of the assessment is 4.58 or $91.5 \%$, thus the assessment of the feasibility of the learning design expert, including the category is very good.

\subsubsection{Feasibility of Expert Material}

Material expert assessment consists of 3 (three) aspects as seen in figure 12, namely the preparation of learning materials, presentation of learning materials, and assessment tools. An assessment of the question items is given in the scaling score $1-5$, and comments / input for improvement / revision.

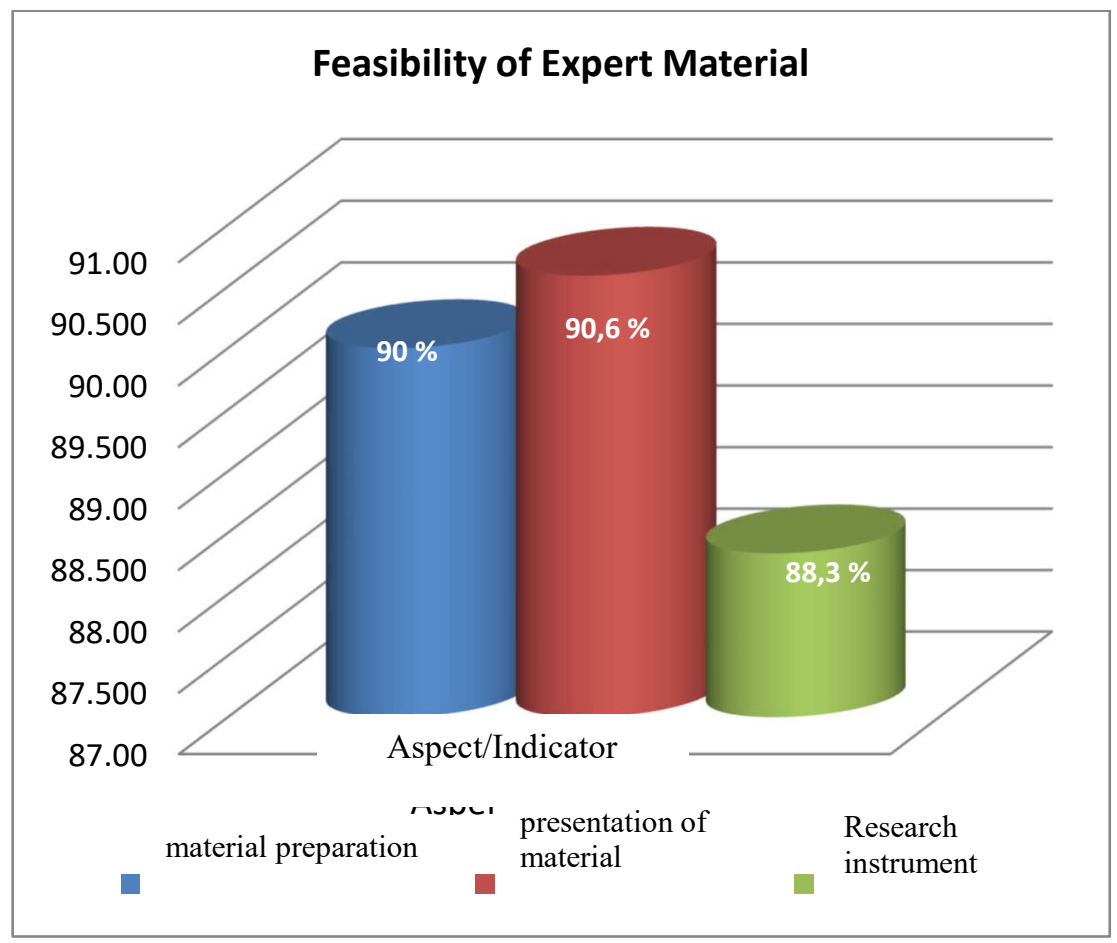

Fig 12. Average Score of Material Expert Eligibility Results

Of the three aspects judged by the material experts, the average score obtained was 4.48 or $89.6 \%$ and included in the excellent category. 


\subsubsection{Feasibility of Learning Experts}

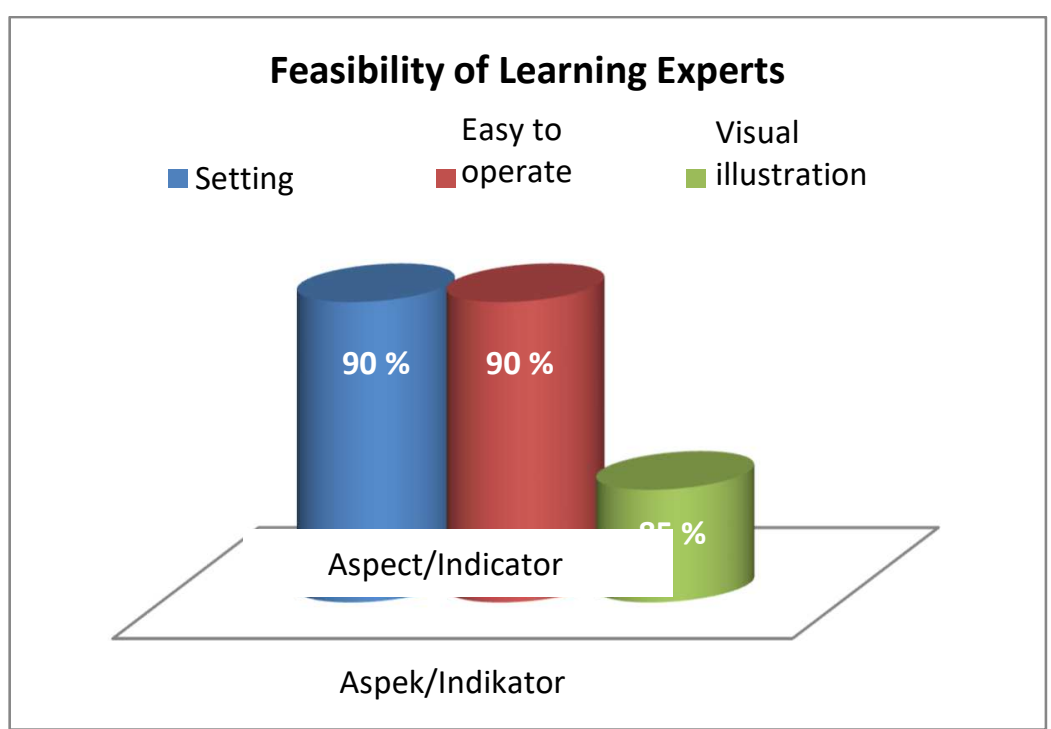

Fig 13. Mean Score Diagram of Learning Media Expertise Eligibility Results

From the feasibility of instructional media experts as shown in figure 13 gave a mean score of 4.42 or $88.3 \%$ and included in the category of very good. The eligibility of the expert gave an average score of 4.52 with a Likert scale of 5 or $90.4 \%$.

\subsection{Effectiveness of Interactive Multimedia}

Table 1. Effectiveness of Test Score

\begin{tabular}{clccc}
\hline No & & Test & Average Score & $(\%)$ \\
\hline 1 & One to one test & 4,44 & $88,8 \%$ \\
2 & Small Group Test & 4,42 & $88,4 \%$ \\
3 & Pretest and posttest & 36,83 & $90,95 \%$. \\
\hline
\end{tabular}

Interactive multimedia has been declared effective proven by an increase in student learning outcomes by $90.95 \%$ (pre-test and post-test results) as shown in table 1 . 


\section{Conclusion}

Procedural development is in line with the Gerlach and Ely models that have been modified with Dick and Carey. The physical form of the development results in the form of interactive textbooks and multimedia learning materials stored on presentation CDs. The mean score given by the learning design expert is 4.58 or $91.5 \%$, the expert judgment of the material average score obtained is 4.48 or $89.6 \%$, the learning media expert assessment gives a mean score of 4.42 or $88.3 \%$ and includes very good categories. The effectiveness of the learning material is done at the end of the physical test by carrying out the post-test, based on the calculation of the mean pre-test value is 40.50 and the post-test average is 77.33. Judging from the results of the pre-test and post-test scores an increase of 36.83 or $90.95 \%$. This means that there is an increase in learning outcomes during the learning process of the Material Testing course by using the learning material development results that have been applied.

\section{References}

[1] Semiawan, Conny R. Pendidikan Tinggi Peningkatan Kemampuan Manusia Sepanjang Hayat Seoptimal Mungkin. Jakarta: Dirjen Dikti. (2013)

[2] Simonson, Michael R. \& Ann Thompson. Educational Computing Foundations (2 ${ }^{\text {nd }}$ ed). Columbus: Merrill Publishers. (2014)

[3] Miarso, Yusufhadi. Survei Model Pengembangan Instruksional. "makalah" Jakarta:Pascasarjana Universitas Negeri Jakarta. (2007)

[4] Robins, Stephen P. Organizational Behavior Concepts, Controversies, Aplications. $7^{\text {th }}$ ed. NY: Prentice-Hall International, Inc. (1996)

[5] Miarso, Yusufhadi. Survei Model Pengembangan Instruksional. "makalah" Jakarta:Pascasarjana Universitas Negeri Jakarta. (2007)

[6] Gustafson, Kent L. and Robert Maribe Branch. Survey of Instructional Development Models. New York: Eric Clearinghouse on Information \& Technology Syracuse University. (2012)

[7] Seels, Barbara B., Rita C. Richey. Teknologi Pembelajaran: Defenisi dan Kawasannya. Jakarta: IPTPI. (1994)

[8] Schwier, Richard A. \& Earl R. Misanchuk. Interactive Multimedia Instruction. New Jersey: Educational Technology Publications, Inc. (2013) 